\title{
Research on Entrepreneurial Service System based on E-Commerce Background
}

\author{
Jia Cheng \\ Jiangxi Vocational College of Industry \& Engineering \\ cjia789@126.com
}

Keywords: E-Commerce, Employment Service, System Innovation

\begin{abstract}
With the development of science and technology, e-commerce has gradually integrated into People's Daily life. As the Internet has become more and more popular, many industries have joined the big family of Internet, which facilitates People's Daily life and increases the employment rate of college graduates. We will allocate resources rationally, ensure smooth employment information, and reduce the emergence of labor shortages. There is still a lot of room for the development of college service employment system, which needs to be explored by us. Based on the background of e-commerce, we constantly improve the entrepreneurial service system. In particular, there is great room for development in the service system of the university, which requires us to constantly expand our thinking, optimize and innovate, and make steady progress.

In the production and life of modern society, the commercial competition is getting fiercer and fiercer, and the traditional industry tends to be saturated. As a result, electronic network competition has gradually emerged, and e-commerce has gradually stepped onto a larger platform that is known by people. With the rise of e-commerce, the economic development mode gradually presents a refined and intensive management mode. Innovation is the first motive force for development. Under the background of the prosperity of e-commerce, strengthening entrepreneurship and innovation has become a greater opportunity and challenge. The awareness of innovation is an important factor of spiritual development. College students have sufficient quality to start their own businesses. They are emerging vitality. In this entrepreneurial frenzy, college students are the driving force and the driving force of entrepreneurship. How to guide the ideological thinking of college students and how to explore the appropriate entrepreneurial path are all problems, which are the main problems at the present stage. We should constantly improve and build the appropriate support service system, incorporate the innovative thinking, and conduct systematic analysis and guidance in practice.
\end{abstract}

\section{Characteristics of Entrepreneurial Service System in the Context of E-Commerce}

\subsection{Information coverage is relatively broad}

Based on the basis of e-commerce, the Internet has comprehensively covered our life, making the employment service innovation system of colleges and universities more perfect, cross-border integration, more diversified service modes and service types, and abundant information subjects. The sharing of e-commerce and the timely acquisition of all kinds of information through the Internet make employers, social organizations, universities and students build a bridge. It is that the resource sharing is fully utilized. Diversified subjects can face all kinds of characteristics and job requirements in different environments and modes. The employment level information and the hidden resource information behind can be Shared in a timely manner, and the comprehensive development is more sufficient, so as to facilitate people's production and life, and resources are 
effectively connected.

\subsection{Establishment of college employment service system}

In the period of rapid development of the Internet, recruitment methods of traditional industries have been gradually replaced, and recruitment information methods have undergone a qualitative change. The Internet fully integrates with traditional industries, breaking through such problems as imperfect recruitment information, asymmetrical matching of recruitment and small communication of confidence, which greatly increases timeliness and operability. So that its spread more extensive, early social undertakings and enterprises and institutions and colleges and universities effective docking, give full play to the professional talent, better meet the needs of the society and people. This brings a new opportunity for college employment and entrepreneurship. A systematic and targeted analysis of students' actual needs and development direction can help students better meet their development and provide more systematic and scientific Suggestions for their entrepreneurial and employment development. To make information communication and feedback present the development mode of three-dimensional painting, which requires students to have sufficient innovation ability. Through various kinds of software for online employment and entrepreneurship, as well as the arrangement and design of offline entrepreneurship courses, it is not limited to the single-line publicity method of the school, and a better guidance mode, which makes the resource market more three-dimensional and keeps optimizing and upgrading, and the establishment of the employment and entrepreneurship service system of the university is more perfect.

\section{Problems and Solutions Presented in the Entrepreneurial Service System Under THE Current Electronic Information Background}

\subsection{College employment service platform needs to be improved}

Career planning is an important course that can effectively guide college students' entrepreneurship and employment. But in general, this course is only offered in the first grade, which leads to fracture problems and defects, making it impossible for students to find their orientation in sophomore and junior years, as well as how to move towards a better career planning path in the future. Education has a certain lag, which makes the employment and entrepreneurship service system of colleges and universities not perfect, the service means and goals are not clear, the content is backward, the update speed is slow, the quality is not good and the communication is not broad enough. In this process, there is a lack of a coherent whole. there are some other ways for college students to find suitable positions. For example, education activities are also mentioned in various training courses they attend. Although they can understand a part of their positioning, adjust their status and construct a more systematic plan, But lack of continuity, college students need more employment guidance, to improve, optimize, upgrade and correct various employment problems in a timely manner, to increase the value of employment guidance.

\subsection{Establishment and practical application of employment service system}

The traditional entrepreneurial service platform gradually presents some disadvantages, which cannot meet the current demand, mainly reflected in the lack of resource information. In the actual development of most colleges and universities, there is no perfect employment platform, capital input, personnel technology, resource maintenance and other related contents, which are initially established, but it is more important to develop ahead and improve efficiency, so as to timely repair, optimize and upgrade relevant problems and play a good guiding role. In addition, in order to 
encourage college students to start their own businesses, the state has introduced relevant preferential policies, and colleges and universities have established employment and entrepreneurship incubation base, which has become an important way to cultivate college students' innovative awareness and improve their practical ability. But most local response the government called on, but the specific implementation of not doing enough perfect, problems such as insufficient funds, limited space, limited resources, teachers lack, equipment is not complete, we one by one, and so on related issues are yet to be solved, integrate these more issues, to better guide the development of college students, improve the success rate of college students' self-employment in the practical work, drive economic growth, create more wealth.

\section{How TO Better Guide College Students TO Independently Innovate, Start Businesses and Obtain Employment}

3.1 We will improve the reward system and cultivate college students' awareness of entrepreneurship

Regularly carry out meaningful activities in campus life, such as student achievement report meeting, excellent entrepreneurship activity, individual career planning and design of students and some internship experience, which have a good incentive effect on students' awareness of innovation and service. Guiding college students through scientific and effective methods can comprehensively improve the quality of students, set up scientific innovative ideas, give students different themes, and increase the number of education activities. It is also very important to build a strong entrepreneurial atmosphere environment, to drive students' positive thoughts, render up positive, positive, energetic, entrepreneurial and development atmosphere, so that students can use it to express their emotions, strengthen publicity, and make unremitting efforts for better entrepreneurship.

3.2 We will improve relevant policies and strengthen college students' entrepreneurial support

Entrepreneurship support policies are continuously optimized and improved to better help college students to achieve self-employment. According to the actual needs of various aspects, based on the organization structure of youth entrepreneurship service institutions, the entrepreneurial experience of college graduates, tax reduction and exemption, the establishment of training bases, and the intensity of financial subsidies, the integration of information from various aspects can effectively promote the entrepreneurial development of college students on the basis of electronic commerce. In addition, deepening the financing structure, providing students with material security, entrepreneurship support and various laws and policies on e-commerce entrepreneurship, and establishing a more complete financing platform through coordinated development of financing institutions, so as to provide students with necessary entrepreneurial support. Through the financial department's contribution to the construction of college start-up fund, use marketization operation and development, drive the private capital to strengthen the financing power fundamentally. Continuously strengthen industrial construction and development, comprehensively promote e-commerce demonstration base, build perfect the whole system, promote the success rate for students in entrepreneurship, college employment development mode innovation, perfect, through the school, society, government and enterprise's related support continuous integration into a whole fundamentally solve the problems existing in the employment business system of university. 


\section{Conclusion}

Under the background of electronic commerce, college students' independent innovation entrepreneurship perfecting employment system, and presents the diversification, systematic characteristics of coverage also gradually expanding, under national policy support, perfecting related reward system in university, to form a more effective innovation service system, and help docking colleges and social resources, improve college students' entrepreneurial success rate of employment.

\section{References}

[1] Sheng $\mathrm{Li}$, wang yujuan. Construction of an ecosystem of college employment and entrepreneurship services in the era of "Internet $+"$ [J]. Henan education,2016(12).[2] Jiang Xiantao.

[2] Zhang Liulu. The entrepreneurial service system of college students from the perspective of public management [J]. Guangdong social science,2013(06):53-59. 